PeCh, B. and J. BRUneton (1982): Alcaloïdes du laurier noble, Laurus nobilis. Journal of Natural Product 45 , 560-563.

Petit, R. J., J. Duminil, S. Fineschi, A. Hampe, D. SAlvini and G. G. VENDRAMIN (2005): Comparative organization of chloroplast, mitochondrial and nuclear diversity in plant populations. Molecular Ecology 14, 689-701.

QiU, Y. L., J. Lee, F. Bernasconi-Quadroni, D. E. Soltis, P. S. Soltis, M. Zanis, E. A. Zimmer, Z. Chen, V. Savolainen and M. W. Chase (1999): The earliest angiosperms: evidence from mitochondrial, plastid and nuclear genomes. Nature 402, 404-407.

QuÉzEL, P. and F. MÉDAIL (2003): Ecologie et biogéographie des forêts du bassin méditerranéen. Elsevier (Collection Environnement), Paris, 573 p.

Rodríguez-Sánchez, F., B. Guzmán, A. Valido, P. Vargas and J. Arroyo (2009): Late Neogene history of the laurel tree (Laurus L., Lauraceae) based on phylogeographical analyses of Mediterranean and Macaronesian populations. Journal of Biogeography, online first.

SAYAH, M., J. VALIZADEH and M. KAMALINEJAD (2002): Anticonvulsant activity of the leaf essential oil of Laurus nobilis against pentylenetetrazole- and maximal electroshock-induced seizures. Phytomedicine 9, 212-216.
Schnell, R. J., J. S. Brown, C. T. Olano, E. J. Power and C. A. KROL (2003): Evaluation of avocado germplasm using microsatellite markers. The American Society for Horticultural Science 128 (6), 881-889.

Sharon, D., P. B. Cregan, S. Mhameed, M. Kusharska, J. HiLlel, E. LAHAV and U. LAVI (1997): An integrated genetic linkage map of avocado. Theoretical Applied Genetics 95, 911-921.

Soto, A., Z. LORENZO and L. GIL (2003): Nuclear microsatellite markers for the identification of Quercus ilex L. and Q. suber L. hybrides. Silvae Genetica 52 (2), 63-66.

Van Oosterhout, C., W. F. Hutchinson, D. P. M. Wills and P. SHIPLEY (2004): MICRO-CHECKER: software for identifying and correcting genotyping errors in microsatellite data. Molecular Ecology Notes 4, 535-538.

Valbuena-Carabana, M., S. C. GonZalez-Martinez and L. GIL (2008): Coppice forests and genetic diversity: A case study in Quercus pyrenaica Willd. from Central Spain. Forest Ecology and Management 254, 225-232.

WEISING, K. and R. C. GARDNER (1999): A set of conserved PCR primers for the analysis of simple sequence repeat polymorphisms in chloroplast genomes of dicotyledonous angiosperms. Genome 42, 9-19.

\title{
Transfer of Microsatellite Loci For The Tropical Tree Prunus africana (Hook. f.) Kalkman
}

\author{
By S. CAVERS ${ }^{\left.1,{ }^{*}\right)}$, R. C. MunRo ${ }^{1)}$, C. A. C. KADU ${ }^{2)}$ and H. KonRAD ${ }^{2)}$ \\ (Received $27^{\text {th }}$ October 2008)
}

\begin{abstract}
Using databases of previously published primers, we optimised six nuclear microsatellite markers for Prunus africana for the purposes of studying spatial genetic structure and gene flow. To assess variability, these and three previously transferred loci were screened in populations from Kenya and South Africa. Across both popu-

\footnotetext{
1) Centre for Ecology \& Hydrology, Bush Estate, Penicuik, Midlothian, EH26 0QB, UK.

2) Federal Research and Training Centre for Forests, Natural Hazards and Landscape Department of Genetics Unit of gene conservation and nurseries, A-1140 Wien, Hauptstraße 7, Austria.

*) Correspondence: Stephen CAVERS, Tel: +44 1314458552 , Fax: +44 131445 3943. E-mail: scav@ceh.ac.uk
}

lations most loci were polymorphic, with the exception of a single locus which failed to amplify in the South African samples, exhibiting between 2 and 22 alleles and levels of expected heterozygosity $(\mathrm{He})$ ranged from 0.059 to 0.932 . Departures from Hardy-Weinberg equilibrium were detected for all loci but not for all populations. The estimated null allele frequency was very low to moderate and no evidence for linkage disequilibrium was detected.

Key words: Prunus africana, nuclear microsatellites, gene flow, genetic diversity.

\section{Introduction}

The African tree species, Prunus africana (Hook. f.) Kalkman (Rosaceae), also known as the African Cherry, 
is a large (to $40 \mathrm{~m}$ ) tree, with predominantly insect pollination and animal dispersed seed (HALL et al., 2000). It is distributed primarily in Afromontane East and Southern Africa, but also occurs in Cameroon and Madagascar. The species has become highly valuable, due to the production of a phytotherapeutic agent extracted from its bark, which is used in the treatment of benign prostatic hyperplasia (HALL et al., 2000). Unsustainable bark extraction methods combined with general forest fragmentation pose a significant, ongoing threat to the species and in 1995 it was listed on Appendix II of CITES in an attempt to control international trade. Due to the species' substantial economic importance to subSaharan African economies and the continuing threats to existing populations, a considerable research effort is now underway to characterise genetic resources, develop domestication methods and devise management strategies to preserve and restore remaining populations. To date, primarily for the purposes of genetic resource management, two studies of rangewide genetic variability have been conducted using RAPDs (DAwson, PowELL, 1999; MUCHUGI et al., 2006) revealing substantial intraspecific differentiation. Later studies by (FARWIG, 2005; FARWIG et al., 2008) used a set of six microsatellite markers transferred from $P$. persica to examine transgenerational loss of genetic diversity due to human forest disturbance. Attention is now focussing on quantifying population-scale gene flow processes to understand local gene dispersal dynamics, mating system and to provide a framework for management of the genetic consequences of germplasm movement in restoration/plant- ing efforts. To provide sufficient resolution for paternity analysis, and due to unreliability of three of the markers (UDP96-001, UDP98-406, pchcms5) previously transferred by FARWIG et al. (2008), broad testing of the extensive microsatellite marker database available for the genus Prunus was undertaken to optimise additional, sufficiently informative markers.

\section{Methods}

A total of 15 microsatellite markers, selected from the literature on the basis of level of polymorphism, were screened against a test set of ten individuals. The full set of loci tested was EMPa001, 004, 005, 009, 010, 011, 013, 014, 015, 016, 018 (CLARKE and ToBUTt, 2003) and EMPaS01, S02, S06, S10 (VAughan and Russell, 2004). A set of six further loci, previously transferred to P. africana (FARWIG et al., 2008) was examined in parallel. Test DNAs were extracts from cambium tissue taken from mature trees in Kibiri Forest, Western Kenya and dried thoroughly on silica gel. DNA was extracted by grinding the dried cambium to a fine powder and processing samples using DNeasy Plant mini kit (QIAGEN) following the manufacturer's protocol. Following preliminary PCR amplification, a set of six loci displaying clear, reproducible fingerprints were selected for optimisation. All microsatellites were amplified using $25.0 \mu \mathrm{l}$ PCR reactions consisting of the following: $1.0 \mu \mathrm{l}$ template DNA, $20.0 \mu \mathrm{l} \mathrm{H}_{2} \mathrm{O}, 0.2 \mu \mathrm{M}$ of each primer, $2.5 \mu \mathrm{l}$ 10X buffer, $0.5 \mu l$ dNTPs (Promega), $0.4 \mu \mathrm{l}$ BSA, 1 U Taq DNA polymerase (New England Biolabs). Reactions

Table 1. - Primer sequences, characteristics and basic descriptive statistics of microsatellites optimised for Prunus africana.

\begin{tabular}{|c|c|c|c|c|c|c|c|c|c|c|c|c|}
\hline $\begin{array}{l}\text { Primer name } \\
\text { (Accession } \\
\text { number) }\end{array}$ & $\begin{array}{l}\text { Linkage } \\
\text { groupa }\end{array}$ & Primer sequence 5' $-3{ }^{\prime}$ & Repeat motif & Population & $\begin{array}{l}\text { Allele size } \\
\text { range (bp) }\end{array}$ & $\mathrm{Na}$ & HIo & He & IIWE & $\begin{array}{l}\text { Null } \\
\text { allele } \\
\text { freq. }\end{array}$ & $\operatorname{Pr}\left(\mathrm{Ex}_{1}\right)$ & $\operatorname{Pr}\left(\Gamma \times x_{2}\right)$ \\
\hline $\begin{array}{l}\text { UDP96-018 } \mp^{1} \\
\text { (BV079701) }\end{array}$ & G1 & $\begin{array}{l}\text { F: TTCTAATCTGGGCTATGGCG } \\
\text { R: GAAGTTCACATTTACGACAGGG }\end{array}$ & {$[\mathrm{AC}]_{21}$} & $\begin{array}{l}\text { Kibiri (KE) } \\
\text { Mpumalanga (ZA) }\end{array}$ & $\begin{array}{l}244-258 \\
248-250\end{array}$ & $\begin{array}{l}7 \\
1\end{array}$ & $\begin{array}{l}0.750 \\
0.000\end{array}$ & $\begin{array}{l}0.740 \\
0.000\end{array}$ & - & $\begin{array}{l}0.000 \\
-\end{array}$ & 0.658 & 0.480 \\
\hline $\begin{array}{l}\text { UDP97-403 } \neq^{1} \\
\text { (BV079702) }\end{array}$ & G3 & $\begin{array}{l}\text { F: CTGGCTTACAACTCGCAAGC } \\
\text { R: CGTCGACCAACTGAGACTCA }\end{array}$ & {$[\mathrm{AG}]_{22}$} & $\begin{array}{l}\text { Kibirl (KE) } \\
\text { Mpumalanga (ZA) }\end{array}$ & $\begin{array}{l}141-149 \\
144\end{array}$ & $\begin{array}{l}2 \\
1\end{array}$ & $\begin{array}{l}1.000 \\
0.000\end{array}$ & $\begin{array}{l}0.500 \\
0.000\end{array}$ & $* * *$ & $\begin{array}{l}0.000 \\
-\end{array}$ & 0.875 & 0.813 \\
\hline $\begin{array}{l}\text { p512a02 } \neq^{2} \\
(\text { AB476763) }\end{array}$ & G4 & $\begin{array}{l}\text { F: GCCACCAATGGTTCTTCC } \\
\text { R: AGCACCAGATGCACCTGA }\end{array}$ & {$[\mathrm{GA}]_{21}$} & $\begin{array}{l}\text { Kibiri (KE) } \\
\text { Mpumalanga (ZA) }\end{array}$ & $\begin{array}{l}147-185 \\
146-152\end{array}$ & $\begin{array}{l}13 \\
4\end{array}$ & $\begin{array}{l}1.000 \\
0.316\end{array}$ & $\begin{array}{l}0.895 \\
0.389\end{array}$ & $\begin{array}{l}\text { ns } \\
\text { ns }\end{array}$ & $\begin{array}{l}0.000 \\
0.102\end{array}$ & 0.349 & 0.210 \\
\hline $\begin{array}{l}\mathrm{EMPa010}^{3} \\
\text { (A]564653) }^{-1}\end{array}$ & G2 & $\begin{array}{l}\text { F:TCTGATCAAGAACCCAACCC } \\
\text { R:ATTCTCAATTTGCGGAGTGG }\end{array}$ & {$\left[\mathrm{GA}_{3} \mathrm{GTAACG}[\mathrm{GA}]_{14}\right.$} & $\begin{array}{l}\text { Kibiri (KE) } \\
\text { Mpumalanga (ZA) }\end{array}$ & $\begin{array}{l}95-103 \\
91-127\end{array}$ & $\begin{array}{l}4 \\
2\end{array}$ & $\begin{array}{l}0.850 \\
0.000\end{array}$ & $\begin{array}{l}0.666 \\
0.188\end{array}$ & $\begin{array}{l}\text { ns } \\
* * *\end{array}$ & $\begin{array}{l}0.000 \\
0.208\end{array}$ & 0.756 & 0.595 \\
\hline $\begin{array}{l}\text { EMPa016 } \\
\text { (AJ564659) }\end{array}$ & G1 & $\begin{array}{l}\text { F:CCAAACCCAATTACCCAGAG } \\
\text { R:GCCAATGTGCCAACCAATAAC }\end{array}$ & {$[A G]_{10}$} & $\begin{array}{l}\text { Kibiri (KE) } \\
\text { Mpumalanga (ZA) }\end{array}$ & $\begin{array}{l}176-182 \\
175-181\end{array}$ & $\begin{array}{l}4 \\
4\end{array}$ & $\begin{array}{l}0.750 \\
0.263\end{array}$ & $\begin{array}{l}0.696 \\
0.587\end{array}$ & $\begin{array}{l}\text { ns } \\
* * * *\end{array}$ & $\begin{array}{l}0.000 \\
0.220\end{array}$ & 0.728 & 0.561 \\
\hline $\begin{array}{l}\text { EMPa001 } \\
\text { (A]564644) }\end{array}$ & G1 & $\begin{array}{l}\text { F:GCTCTGCTGCTTCAACCATT } \\
\text { R:TTTCCCAACACACTTACCCC }\end{array}$ & {$\left[\mathrm{AG}_{4} \mathrm{GGGTAG}_{26}\right.$} & $\begin{array}{l}\text { Kibiri (KE) } \\
\text { Mpumalanga (ZA) }\end{array}$ & $\begin{array}{l}147-185 \\
-\end{array}$ & $\begin{array}{l}16 \\
-\end{array}$ & 0.800 & 0.915 & ns & $\begin{array}{l}0.038 \\
-\end{array}$ & 0.294 & 0.172 \\
\hline $\begin{array}{l}\text { EMPaS10 } \\
(\text { AY526626) }\end{array}$ & G4 & $\begin{array}{l}\text { F:GCTAATATCAAATCCCAGCTCTC } \\
\text { R:TGAAGAAGTATGGCTTCTGTGG }\end{array}$ & {$[\mathrm{GA}]_{28}$} & $\begin{array}{l}\text { Kibiri (KE) } \\
\text { Mpumalanga (ZA) }\end{array}$ & $\begin{array}{l}140-172 \\
172-212\end{array}$ & $\begin{array}{l}15 \\
11\end{array}$ & 0.850 & $\begin{array}{l}0.903 \\
0.872\end{array}$ & ** & $\begin{array}{l}0.037 \\
0.115\end{array}$ & 0.329 & 0.197 \\
\hline $\begin{array}{l}\text { EMPaS06 }^{4} \\
\text { (AY526622) }\end{array}$ & G4 & $\begin{array}{l}\text { F:AAGCGGAAAGCACAGGTAG } \\
\text { R: TTGCTAGCATAGAAAAGAATTGTAG }\end{array}$ & {$[\mathrm{CT}]_{12}$} & $\begin{array}{l}\text { Kibiri (KE) } \\
\text { Mpumalanga (ZA) }\end{array}$ & $\begin{array}{l}201-229 \\
196-222\end{array}$ & $\begin{array}{l}10 \\
8\end{array}$ & $\begin{array}{l}0.850 \\
0.789\end{array}$ & $\begin{array}{l}0.826 \\
0.745\end{array}$ & $\begin{array}{l}\text { ns } \\
\text { ns }\end{array}$ & $\begin{array}{l}0.000 \\
0.000\end{array}$ & 0.500 & 0.329 \\
\hline $\begin{array}{l}\text { EMPaS01 } \\
\text { (AY526618) }\end{array}$ & G6 & \begin{tabular}{|l} 
F: CAAAATCAACAAAATCTAAACC \\
R:CAAGAATCTTCTAGCTCAAACC \\
\end{tabular} & {$[\mathrm{GA}]_{9}[\mathrm{GA}]_{11}$} & $\begin{array}{l}\text { Kibiri (KE) } \\
\text { Mpumalanga (ZA) }\end{array}$ & $\begin{array}{l}241-257 \\
230-234\end{array}$ & $\begin{array}{l}8 \\
2\end{array}$ & $\begin{array}{l}0.650 \\
0.316\end{array}$ & $\begin{array}{l}0.790 \\
0.488\end{array}$ & ns & $\begin{array}{l}0.046 \\
0.117\end{array}$ & 0.577 & 0.398 \\
\hline
\end{tabular}

$\$-$ previously optimised for $P$. africana (FARWIG et al., 2008). 1 = CIPRIANI et al., 1999, 2 = Sosinski et al., $2000,3=$ CLARKE and ToBUTt, 2003, 4 = VAUGHAN and RUSSELL, 2004. a - Linkage group position on Prunus avium map: for UDP primers and EMPaS01 from Genomic database for Rosaceae (http://www.bioinfo.wsu.edu/gdr/), ps12a02 from JoobeUR et al. (2000), EMPa001, EMPa010, EMPa016, EMPaS01, EMPaS10, EMPaS06 from ClARKE et al. (2009). Abbreviations are: $\mathrm{Na}=$ number of alleles, $\mathrm{H}_{0}=$ observed heterozygosity, $\mathrm{H}_{\mathrm{e}}$ = expected heterozygosity, HWE - deviation from Hardy-Weinburg Equilibrium, where: ns = not significant $(P>0.05)$; $P<0.05$, ** $P<0.01$; *** $P<0.001, \operatorname{Pr}\left(\mathrm{Ex}_{1 / 2}\right)-$ exclusion probability for first parent (1), second parent (2). Total combined exclusion probabilities: $\operatorname{Pr}\left(\mathrm{Ex}_{1}\right)=0.9970 ; \operatorname{Pr}\left(\mathrm{Ex}_{2}\right)=0.9999$. 
were run on a Hybaid MBS thermocycler to the following protocol: $1 \mathrm{~min}$ at $94^{\circ} \mathrm{C}$, then 35 cycles of $30-45 \mathrm{~s}$ at $94^{\circ} \mathrm{C}, 30-45 \mathrm{~s}$ at annealing temperature, $45-60 \mathrm{~s}$ at $72^{\circ} \mathrm{C}$ and finally $5 \mathrm{~min}$ at $72^{\circ} \mathrm{C}$. Optimal PCR reaction conditions for each of the polymorphic pairs were determined by testing a range of annealing temperatures $\left(55.0-70.3^{\circ} \mathrm{C}\right)$ and different template DNA dilutions (1:1, 1:5, 1:10 and 1:20, from an original concentration of $\left.\sim 50 \mathrm{ngul}^{-1}\right)$. This resulted in the following modifications: primers UDP96-018, UDP97-403 and ps12a02 were amplified at 45 secs per step for the main cycle, with a fixed annealing temp. of $60^{\circ} \mathrm{C}$. Primers EMPa010, 016, 001, S10, S06, S01 were amplified using a touchdown programme with 30 sec. steps and annealing temp reducing from $60-55$ degrees over 10 steps, followed by 25 cycles at fixed annealing temp. of $55^{\circ} \mathrm{C}$. Primer EMPa016 followed the same programme as the latter, but with the annealing steps lengthened to 45 secs. In all cases the forward primer was labelled with either IRD 700 or 800 fluorescent label (MWG Biotech). PCR products were then separated on $6 \%$ polyacrylamide gel $(25 \mathrm{~cm})$, and visualized using a LI-COR 4200 IR2 automated sequencer. PCR products were run out alongside a microSTEP DNA size standard (Microzone Limited) and fragment sizes were scored using SAGA ${ }^{\mathrm{TM}}$ software. Optimised loci were screened in two populations - Kibiri Forest, Western Kenya $(\mathrm{n}=20)$ and Mpumalanga, South Africa $(n=19)$, providing test samples at extreme distance across the natural distribution. Numbers of alleles were calculated, and observed and expected heterozygosity estimated using GenAlEx version 5 (PEAKALL, Smouse, 2006). Null allele rates, tests for Hardy-Weinberg (HWE) and linkage disequilibrium, corrected for multiple comparisons were carried out using Genepop v3.3 (Raymond, Rousset, 1995) and Fstat 2.9.3 (GouDET, 2002). Exclusion probabilities were estimated using Cervus v3.0 (MARSHALl et al., 1998). Results are reported in Table 1.

\section{Results}

All primers amplified in both populations, apart from EMPa001, which failed in Mpumalanga, possibly the result of mutation in the primer binding site - a feasible scenario given that the study populations will likely have been isolated for a long period. The number of alleles found in the three populations ranged from 1 to 16 , with markedly higher levels of polymorphism in Kibiri compared to Mpumalanga. The observed and expected heterozygosities ranged from 0 to 1.000 and from 0 to 0.915 , respectively (Table 1 ). In the Kenyan population significant deviation from Hardy-Weinberg equilibrium was observed at four loci (UDP96-018, UDP97-403, EMPaS10, S01) loci, and no or very low null allele rates were estimated. In the South African population, two loci were monomorphic (UDP96-018, UDP97-403) and three others (EMPa010, 016, S10) showed deviation from HWE $(\mathrm{P}<0.05)$, while no significant deviation was found in ps12a02, EMPaS06, S01. Compared to the Kenyan samples, a larger frequency of null alleles was estimated (maximum 0.22; Table 1). No evidence for linkage disequilibrium was found. The combined exclu- sion probabilities for the nine loci $\left(\operatorname{Pr}\left(\operatorname{Ex}_{1}\right)=0.0030\right.$, $\left.\operatorname{Pr}\left(\mathrm{Ex}_{2}\right)=0.0001\right)$ were high.

\section{Discussion}

The observed patterns of variation at the optimised loci, notably the contrast in levels of polymorphism between Kenyan and South African sites, suggest these markers will be valuable sources of information in future large-scale studies. Locally, the departures from HWE in the Kenyan population are potentially the result of substantial human modification of the population as, during collection, some evidence for enrichment planting or artificial encouragement of $P$. africana natural regeneration was identified. These effects will be explored in fine-scale analysis of the population in a forthcoming study. Finally, the combined exclusion probability of the loci means they will form useful markers for studies of paternity and mating systems in ongoing projects and future work.

\section{Acknowledgements}

This work was supported by the European Community as part of the FOREAIM project (FP6, contract INCOCT-2005-510790, http://foreaim.cirad.fr/) and by the Austrian Development Agency through Bioversity International as part of the project "Development of strategies for the conservation and sustainable use of Prunus africana to improve the livelihood of small-scale farmers".

\section{References}

Cipriani, G., G. Lot, W. G. Huang, M. T. Marrazzo, E. Peterlunger and R. Testolin (1999): AC/GT and AG/CT microsatellite repeats in peach [Prunus persica (L) Batsch]: isolation, characterisation and cross-species amplification in Prunus. Theoretical and Applied Genetics 99: 65-72.

Clarke, J. B. and K. R. TobutT (2003): Development and characterization of polymorphic microsatellites from Prunus avium 'Napoleon'. Molecular Ecology Notes 3: $578-580$.

Clarke, J. B., D. J. Sargent, R. I. Boskovic, A. Belaj and K. R. TobUTT (2009): A cherry map from the inter-specific cross Prunus avium 'Napoleon' x P. nipponica based on microsatellite, gene-specific and isoenzyme markers. Tree Genetics and Genomes 5: 41-51.

DAWson, I. K. and W. Powell (1999): Genetic variation in the Afromontane tree Prunus africana, an endangered medicinal species. Molecular Ecology 8, 151-156.

FARWIG, N. (2005): Impact of forest fragmentation and disturbance on the endangered tropical tree Prunus africana (Rosaceae) M.Sc., Johannes-Gutenburg University.

Farwig, N., B. Bleher, S. von Der Gonna and K. BoHNING-GAESE (2008): Does forest fragmentation and selective logging affect seed predators and seed predation rates of Prunus africana (Rosaceae)? Biotropica 40, $218-224$.

GOUDET, J. (2002): FSTAT version 2.9.3.2. Institute of Ecology, Lausanne, Switzerland. Available from http:// www2.unil.ch/popgen/softwares/fstat.htm. 
HAll, J. B., E. M. O'BRIEN and F. Sinclair (2000): Prunus africana: a monograph, School of Agricultural and Forest Sciences, University of Wales, Bangor.

Joobeur, T., N. Periam, M. C. DE Vicente, G. J. King and P. ARUS (2000): Development of a second generation linkage map for almond using RAPD and SSR markers. Genome 43: 649-655.

Marshall, T. C., J. Slate, L. E. B. KruUk and J. M. PemBERTON (1998): Statistical confidence for likelihoodbased paternity inference in natural populations. Molecular Ecology 7: 639-655.

Muchugi, A., A. G. Lengkeek, C. A. C. Kadu, G. M. MuluVI, E. N. M. NJAGi and I. K. DAWson (2006): Genetic variation in the threatened medicinal tree Prunus africana in Cameroon and Kenya: Implications for current management and evolutionary history. South African Journal of Botany 72: 498-506.
PeAKall, R. and P. E. SMouse (2006): GENALEX 6: genetic analysis in Excel. Population genetic software for teaching and research. Molecular Ecology Notes 6: 288-295.

RAYMOND, M. and F. Rousset (1995): GENEPOP (Version 1.2) - Population genetics software for exact tests and ecumenicism. Journal of Heredity 86: 248-249.

Sosinski, B., M. Gannavarapu, L. D. Hager, L. E. BeCK, G. J. King, C. D. RYder, S. RAJAPAKSE, W. V. BAIRD, R. E. BAllard and A. G. Aвbоtт (2000): Characterization of microsatellite markers in peach [Prunus persica (L.) Batsch]. Theoretical and Applied Genetics 101: 421-428.

VAughan, S. P. and K. Russell (2004): Characterization of novel microsatellites and development of multiplex PCR for large-scale population studies in wild cherry, Prunus avium. Molecular Ecology Notes 4: 429-431.

\title{
Genetic Diversity of an Australian Santalum album Collection - Implications For Tree Improvement Potential
}

\author{
By C. G. Jones ${ }^{1), *)}$, J. A. PlummeR ${ }^{1)}$, E. L. BArbour ${ }^{1), 2)}$ and M. Byrne ${ }^{1), 3)}$ \\ (Received $18^{\text {th }}$ November 2008)
}

\begin{abstract}
The Forest Products Commission of Western Australia manages a sandalwood (Santalum spp.) core germplasm collection at Kununurra in the states far north. This collection serves as a significant seed source for sandalwood plantations in the area and remains an important resource for ongoing research. The collection contains $S$. album trees sourced from Indian arboreta, along with a few trees from West Timor, Indonesia. Also present are representatives of $S$. macgregorii from Papua New Guinea and $S$. austrocaledonicum from Vanuatu and/or New Caledonia. Despite the apparently diverse seed origins, the genetic background of many of the accessions remains vague. In this study, diversity and relatedness was assessed by nuclear and chloroplast RFLPs and a phylogeny was inferred. Nuclear RFLPs revealed very low levels of genetic diversity for a tree species, with an

\footnotetext{
1) School of Plant Biology, University of Western Australia, 35 Stirling Hwy Crawley WA 6009 Australia. Phone: +61 86488 1992. Email: jonescg@cyllene.uwa.edu.au

2) Forest Products Commission of Western Australia, 117 Great Eastern Highway Rivervale WA, 6103, Australia. Email: liz.barbour@fpc.wa.gov.au

3) Western Australian Department of Environment and Conservation, Science Division. Locked Bag 104, Bentley Delivery Centre, WA 6983, Australia. Email: margaret.byrne@dec.wa. gov.au

*) To whom correspondence should be addressed.
}

observed and expected heterozygosity $\left(\mathrm{H}_{0}\right.$ and $\left.\mathrm{H}_{\mathrm{e}}\right)$ of 0.047. Nineteen genotypes were identified within the $233 \mathrm{~S}$. album individuals sampled, with only one tree known to have originated from Timor being differentiated from Indian material. Other trees thought to have come from Timor grouped with those believed to be from India, indicating they were either incorrectly labelled or sourced from heavily modified populations. Despite the poor sample size, chloroplast RFLP analysis revealed no genetic distinction between the Timorese and Indian $S$. album, which supports the theory of human mediated seed dispersal from Timor to India. The structure of the phylogeny and associated relatedness has assisted in the establishment of seed orchards, designed to ensure maximum diversity is maintained through limiting the proximity of highly related trees. Finally, in light of these and other findings, a hypothesis concerning the evolution of $S$. album is proposed.

Key words: Sandalwood, Santalum, genetic diversity, phylogeny, evolution.

\section{Introduction}

Indian sandalwood, S. album (Santalaceae) refers to a small root-parasitic tree renowned for its fragrant heartwood. The ground wood may contain as much as $9 \%$ essential oil (JONEs et al., 2006) and is used in incense and joss stick manufacture, while the oil is used as a fix- 